\title{
REPLACEMENT OF FISH MEAL WITH SUCKERMOUTH ARMORED CATFISH AND ITS EFFECT ON PERFORMANCE AND INTESTINAL MORPHOLOGY OF INDIGENOUS THAI CHICKEN
}

\author{
O. Srinual ${ }^{1}$, M. Punyatong ${ }^{1,2}$, T. Moonmanee ${ }^{1,2,3}$, P. Intawicha ${ }^{4}$, M. Yachai ${ }^{2,5}$, and W. Tapingkae ${ }^{1,2^{*}}$ \\ ${ }^{1}$ Department of Animal and Aquatic Sciences, Faculty of Agriculture, Chiang Mai University, Chiang Mai, Thailand \\ ${ }^{2}$ Innovative Agriculture Research Center, Faculty of Agriculture, Chiang Mai University, Chiang Mai, 50200, Thailand \\ ${ }^{3}$ Laboratory of Histology and Animal Disease Diagnosis, Department of Animal and Aquatic Sciences, Chiang Mai \\ University, Faculty of Agriculture, Chiang Mai, Thailand \\ ${ }^{4}$ Division of Animal Science, School of Agriculture and Natural Resources, University of Phayao, Phayao, Thailand \\ ${ }^{5}$ Faculty of Animal Science and Technology, Maejo University, Chiang Mai, Thailand \\ "Corresponding author's e-mail: wanaporn.t@cmu.ac.th
}

\begin{abstract}
Two hundred, one-day old Thai native chickens were investigated for the effects of growth performance and intestinal morphology, when replacing their fish meal (FM) with suckermouth armored catfish (Pterygoplichthys pardalis) meal (PPM) in diets. Experimental groups were fed ad libitum; the basal diet with 100\% FM (control), and the basal diet with PPM 25\% (T1), 50\% (T2), 75\% (T3), and 100\% (T4). Twenty chickens (4 chickens per each group) were euthanized and small intestinal tissues were collected in order to determine the morphology. From 1-84 days of age; chickens in the control, T1, T2, T3, and T4 groups presented no significant differences $(\mathrm{P}>0.05)$ in growth performances (average daily feed intake, average daily gain, and feed conversion ratio). However, villus height, and villus height per crypt depth ratio were greatest in duodenal, jejunal, and ileal tissue segments of chickens in the $T 1$ group $(\mathrm{P} \leq 0.05)$. Our preferred interpretation is that PPM can may be used to replace FM in chicken diet without any adverse impacts on growth performance. Moreover, our results demonstrate that replacement of FM with PPM can be improved intestinal lumen health, as indicated by villus height.
\end{abstract}

Keywords: Pterygoplichthys pardalis, fish meal, Thai native chickens, productive performance, intestinal lumen health.

https://doi.org/10.36899/JAPS.2020.4.0094

Published online April 25, 2020

\section{INTRODUCTION}

Today's consumers have acquired a taste and preference for native chickens over those of commercial broiler chickens (Moharrery and Mirzaei, 2014). The Pradu Hang Dum chicken is the one of the native chickens of Thailand. Compared to fast-growing chickens, native chicken breeds show lower growth performance and smaller proportions of breast muscle in the carcass; however, their meat has many quality characteristics valued by modern consumers (Sokołowicz et al., 2016; Shafiq et al., 2018). In Thailand, the demand for meat consumption of native chicken is basically higher than supply, as people consider the native chicken meat to be healthier and tastier than commercial broiler meat. This is because the meat of native chickens contains lower fat content, cholesterol, and triglycerides (Jaturasitha et al., 2016). For the survivability of Thailand's native chicken industry, productions costs must be kept as minimum as possible. Total feed costs report for nearly 70 to $80 \%$ of the total cost of chicken production (Chang, 2007; Józefiak et al., 2018), and protein costs at about $13 \%$ of the total cost. In many cases, this type of production may be price prohibitive for smallholder chicken farmers experiencing default economies of scale and limited access to credit. Moreover, several countries have problems with the supply and quality of feed ingredients for their extensive poultry industry; in which feed ingredients and protein sources are limited, making the formulation of a balanced diet especially difficult. The primary ingredient in chicken diets is a fish meal (FM); due to its high level of protein content, high essential amino acid and fatty acid composition, high palatability, and high digestibility for chickens (Donkoh et al., 2001; Cho and Kim, 2011). On the other hand, FM is the most expensive ingredient, and is in very limited supply. The use of cheap protein ingredients as a partial or total replacement for FM in livestock animal diets has become an international research priority. An alternative protein source has been inexpensive, easy to use, and enough for demand. Additionally, it must be found the basal amino acid requirements for poultry, and sufficiently palatable to reduce rejection by chickens (El-Sayed et al., 2018).

The suckermouth armored catfish (Pterygoplichthys pardalis) is an invasive fish species in several regions in Thailand and other Asian countries (Orfinger and Goodding, 2018). It can breed in a variety 
of aquatic habitats, tolerate polluted environments, and has a negative effect for several native fish species by destroying or eating their eggs. Moreover, it has hard scales, except for the stomach area, which is why it is not suitable for human consumption (Orfinger and Goodding, 2018). Furthermore, Indarsih et al. (2016) observed that the effect of feeding suckermouth armored catfish (sapusapu fish) as a single protein source improved egg quality of local duck. The suckermouth armored catfish is a potential feed ingredient for chicken feeding, as well as a dietary protein alternative, and a source of income for the rural poor. However, the potency of the Pterygoplichthys pardalis meal (PPM) as a feed ingredient for chickens requires further study. The nutrient content of PPM, a very important factor in formulating a protein diet, has not been widely recognized. A greater understanding of the Pterygoplichthys pardalis meal (PPM) is essential to the increase in the potency of PPM as a feed ingredient for poultry. Thus, the objective of our study was therefore to evaluate the effects of the FM replacement with PPM in diets on growth performance and intestinal histology in Thai native chickens (Pradu Hang Dam chickens).

\section{MATERIALS AND METHODS}

Experiment location: This experiment was conducted at the Division of Animal Science, School of Agriculture and Natural Resources, University of Phayao, Phayao, Thailand (Latitude: 1902' N / Longitude: 99 54' E). All experiments were conducted according to the guidelines established for the care and use of laboratory animals, and have been approved by Maejo University, Thailand.

Preparation of PPM: The suckermouth armored catfish from Phayao lake (Kwan Phayao) (Latitude: $19^{\circ} 8.5^{\prime} \mathrm{N}$ to $19^{\circ} 12^{\prime} \mathrm{N}$ and Longitude: $99^{\circ} 51^{\prime} \mathrm{E}$ to $99^{\circ} 55^{\prime} \mathrm{E}$ ), Phayao province, Thailand were used to prepared the PPM. Those weighing between 200-300 g and over were slain. The internal organs were removed from the body's internal cavity. Each fish sample was granulized using a cutting mill to a small piece $(0.5-1.0 \mathrm{~mm})$. A small particle size was dried in a hot air oven at $60^{\circ} \mathrm{C}$ for $48 \mathrm{~h}$.

Chemical compositions analysis: Dry matter, ash, crude fat, crude fiber, and crude protein were measured within the PPM according to the AOAC (2012). The chemical composition and amino acid profiles of the FM and PPM were determined in triplication. Gross energy was determined using a bomb calorimeter, and amino acid profiles were conducted according to White et al. (1986). The HPLC system (Shimadzu Isocratic System, Japan) was employed for the determination of amino acids using a Restek's Ultra IBD column (Pennsylvania, USA). The chemical compositions and amino acid profiles of the FM and PPM are demonstrated in Table 1 and Table 2, respectively.
Chickens and nutritional treatments: A total of 200, straight-run Thai native chickens (Pradu Hang Dam chickens), from the Department of Livestock Development, Phayao Province, Thailand, was used in this study (January to March 2019). The experiment was designed as a completely randomized design. The experimental birds were distributed into 5 nutritional treatments, with 4 replicates of 10 birds each. The treatment groups received the following diets for 12 weeks: basal diet with 100\% FM (control group), and basal diet with 25\% PPM (T1 group), 50\% PPM (T2 group), 75\% PPM (T3 group), and 100\% PPM (T4 group). The chickens received the experimental diets and clean water ad libitum during the experimental period. The experimental diets were formulated to meet poultry requirements for nutrients (NRC, 1994) (Table 3). Feed intake, body weight, and feed efficiency were recorded weekly, and analyzed. Thereafter, average daily gain (ADG), average daily feed intake (ADFI), and feed conversion ratio (FCR) were evaluated.

Intestinal tissue sampling and preparation: Twenty Thai native chickens (4 chickens per each dietary group) were euthanized (cervical dislocation) at 84 days of age. The gastrointestinal tract from the proventriculus to the end of the intestine was excised. The small intestine was collected in order to obtain a $10-15 \mathrm{~cm}$ sample. The tissue samples were then cut into 3 segments that included duodenal, jejunal, and ileal parts (Khambualai et al., $2009 b$ ). Each segment of small intestine was sectioned into 2.0-3.0 $\mathrm{cm}$ pieces. The intestinal segments were washed in ice-cold PBS by flushing intestine with a syringe. The duodenal, jejunal and ileal tissue segments were cut into a $1.0 \mathrm{~mm}$ piece and fixed in the $10 \%$ neutral buffered formalin for $24 \mathrm{~h}$. After fixation, the small intestinal tissue was dehydrated in alcohol solutions of increasing concentrations (from $10 \%$ to absolute), infiltrated with xylene, and embedded in paraffin wax. Each section was then cut to a $4 \mu \mathrm{m}$ thickness via a microtome machine (Medite model A550, Burgdorf, Germany), affixed to a glass slide, and heated at $40 \mathrm{C}$ until the samples and paraffin were dried. The intestinal tissue sample was stained with Haematoxylin and Eosin (Rakowska et al., 1993). In this experiment, sixty images per each treatment were used to analyze intestinal morphology. The histological sections were evaluated (10 $\times$ magnification) via a compound microscope (A1 Zeiss Axio Scope, Germany) and visualized using a highquality digital camera (Canon EOS-6D mark, Canon USA, Inc.), in order to evaluate the morphometric parameters of the small intestine. Thereafter, the morphometric parameters (villus height, villus width, crypt width, crypt depth, crypt area, muscularis mucosae thickness, and villus height per crypt depth ratio) were quantified according to the procedures described by Tapingkae et al. (2016) with the use of Motic Images 
Plus 2.0 software (Motic China Group Co, Fujian, China).

Statistical analysis: Growth performance and intestinal morphology were analyzed using one-way ANOVA. The differences between the means of growth performance and intestinal morphology were evaluated by Duncan's New Multiple Range Tests. The linear and quadratic effects of the increasing levels of PPM on growth performance were also analyzed. Significance was considered at $\mathrm{P} \leq 0.05$. The tests were carried out through the using SPSS software (Version 23.0; SPSS Inc., Chicago, IL, USA).

\section{RESULTS}

Growth performance of the Pradu Hang Dum chickens: The initial and final weights did not differ $(\mathrm{P}>0.05)$ among experimental groups. During the first 128 days of age (Phase 1$)$, the ADG was greater $(\mathrm{P} \leq 0.01)$, and the FCR lower $(\mathrm{P} \leq 0.05)$ in the $\mathrm{T} 1$ group compared with the control, T2, T3, and T4 groups (Table 4). During the 29-84 days of age (Phase 2), ADFI, ADG, and FCR did not differ $(\mathrm{P}>0.05)$ among experimental groups (Table 4). Overall, days 1-84, chickens in the control, T1, $\mathrm{T} 2, \mathrm{~T} 3$, and $\mathrm{T} 4$ groups presented no significant difference in ADFI, ADG, and FCR ( $\mathrm{P}>0.05)$ (Table 4). Moreover, there were no linear and quadratic relationships between replacement FM with PPM level and growth performance (Table 4).

Duodenal histology: Figure 1 illustrates light photomicrographs of Hematoxyline and Eosin-stained duodenal tissues of Pradu Hang Dam chickens that received the basal diet with 100\% FM (control; Fig. 1A), and the basal diet with PPM 25\% (T1; Fig. 1B), 50\% (T2; Fig. 1C), 75\% (T3; Fig. 1D), and 100\% (T4; Fig. 1E). Chickens that received a basal diet of $25 \%$ PPM (T1) had a greater villus height of the duodenal tissue section $(\mathrm{P} \leq 0.01)$, compared with the T3, T4, T2, and control groups (Table 5). On the other hand, the villus width of the duodenal tissue section was greater in the control group than in groups T1, T3, T4, and T2 (Table 5). Crypt depth of the duodenal tissue section did not differ $(\mathrm{P}>0.05)$ among dietary treatments (Table 5). Chickens in the T4 group that were fed a basal diet of $100 \%$ PPM replacing FM showed a decrease in crypt width of the duodenal tissue section ( $\mathrm{P} \leq 0.05$; Table 5). Crypt area was lowest $(\mathrm{P} \leq 0.01)$ in the duodenal tissue section of chickens fed the $100 \%$ FM diet (control group; Table 5). Muscularis mucosae thickness was greatest in the control group compared with groups T2 and T3, but was not different when compared with groups $\mathrm{T} 1$ and $\mathrm{T} 4(\mathrm{P} \leq 0.05$; Table 5). Villus height per crypt depth ratio was greatest $(\mathrm{P} \leq 0.01)$ in the duodenal tissue sections of chickens receiving a basal diet with 25\% PPM replacing FM (T1) (Table 5).

Jejunal histology: Figure 2 shows light photomicrographs of Hematoxyline and Eosin-stained jejunal tissues of chickens that received the basal diet with 100\% FM (control; Fig. 2A), and the basal diet with PPM 25\% (T1; Fig. 2B), 50\% (T2; Fig. 2C), 75\% (T3; Fig. 2D), and 100\% (T4; Fig. 2E). Villus height was greatest $(\mathrm{P} \leq 0.05)$ in the jejunal tissue section of chickens receiving a basal diet with PPM replacing FM at 25\% (T1) (Table 6). Villus width was greatest in the control group compared with groups T1, T3, and T4; but no difference was observed when compared with the T2 group ( $\mathrm{P}=0.05$; Table 6 ). Crypt depth, crypt width, and muscularis mucosae thickness did not differ $(\mathrm{P}>0.05)$ among the experimental groups (Table 6). Crypt area was greater $(\mathrm{P} \leq 0.01)$ in the jejunal tissue section of the control group versus groups T4, T3, T2, and T1 (Table 6). Chickens that received a basal diet with PPM replacing FM at 25\% (T1) had a greater villus height per crypt depth ratio compared with $\mathrm{T} 2, \mathrm{~T} 3, \mathrm{~T} 4$, and the control groups $(\mathrm{P} \leq 0.01$; Table 6$)$.

Ileal histology: Figure 3 demonstrates light photomicrographs of Hematoxyline and Eosin-stained ileal tissues of chickens that received the basal diet with $100 \%$ FM (control; Fig. 3A), and the basal diet with PPM 25\% (T1; Fig. 3B), 50\% (T2; Fig. 3C), 75\% (T3; Fig. 3D), and $100 \%$ (T4; Fig. 3E). Chickens that received a basal diet with PPM replacing FM at 25\% (T1) had greater $(\mathrm{P} \leq 0.01)$ villus height compared with chickens in the control, T2, T3, and T4 groups (Table 7). Villus width was greatest in the T4 group, compared with the control, $\mathrm{T} 1$, and T3 groups; but was not different compared with group T2 ( $\mathrm{P} \leq 0.01$; Table 7$)$. Crypt depth was greatest $(\mathrm{P} \leq 0.01)$ in the ileal tissue section of chickens receiving a basal diet with PPM replacing FM at 75\% (T3) (Table 7). Crypt area was greatest $(\mathrm{P} \leq 0.01)$ in the ileal tissue section of the T2 group (Table 7). Crypt width was greatest in the ileal tissue section of the control group, compared with group T3, but was not different when compared with groups T1, T2, and T4 $(\mathrm{P} \leq 0.01$; Table 7). Dietary treatments had no effect $(\mathrm{P}>0.05)$ on muscularis mucosae thickness in the ileal tissue section of chickens (Table 7). Moreover, chickens receiving a basal diet with PPM replacing $\mathrm{FM}$ at $25 \%$ (T1) had higher villus height per crypt depth ratio $(\mathrm{P} \leq 0.01)$, compared with chickens in the control, T2, T3, and T4 groups (Table 7). 
Table 1 Chemical compositions of FM and PPM

\begin{tabular}{lccc}
\hline \multicolumn{1}{c}{ Chemical composition } & FM $^{*}$ & PPM $^{*}$ & P-value \\
\hline Dry matter $(\%)^{\dagger}$ & $86.78 \pm 0.391^{\mathrm{b}}$ & $97.01 \pm 0.571^{\mathrm{a}}$ & $\leq 0.001$ \\
Ash (\%) & $20.96 \pm 0.026^{\mathrm{b}}$ & $25.14 \pm 0.147^{\mathrm{a}}$ & $\leq 0.001$ \\
Ether extract (\%) & $9.73 \pm 0.014^{\mathrm{a}}$ & $6.00 \pm 0.231^{\mathrm{b}}$ & $\leq 0.001$ \\
Crude fiber (\%) & $0.44 \pm 0.006^{\mathrm{a}}$ & $0.04 \pm 0.032^{\mathrm{b}}$ & $\leq 0.001$ \\
Crude protein (\%) & $56.99 \pm 0.018^{\mathrm{b}}$ & $62.18 \pm 0.100^{\mathrm{a}}$ & $\leq 0.001$ \\
Nitrogen free extract (\%) & $11.89 \pm 0.053^{\mathrm{a}}$ & $6.62 \pm 0.415^{\mathrm{b}}$ & $\leq 0.001$ \\
Gross energy (kcal/g) & $3905 \pm 2.905^{\mathrm{a}}$ & $3869 \pm 3.511^{\mathrm{b}}$ & 0.001 \\
\hline
\end{tabular}

${ }^{a, b}$ Means in the same row with different superscripts differed by t-test.

${ }^{*}$ Data are expressed as mean \pm standard error of mean.

$\dagger$ Dry matter of FM and PPM are air-dry basis, others are dry-matter basis.

Abbreviations: FM, fish meal; PPM, suckermouth armored catfish meal.

Table 2 Amino acid compositions of FM and PPM (mg/g)

\begin{tabular}{|c|c|c|c|}
\hline Amino acid & FM $^{*}$ & PPM $^{*}$ & P-value \\
\hline \multicolumn{4}{|l|}{ Essential amino acid } \\
\hline Histidine & $30.07 \pm 0.018^{\mathrm{a}}$ & $29.52 \pm 0.009^{b}$ & $\leq 0.001$ \\
\hline Isoleucine & $22.20 \pm 0.009^{\mathrm{a}}$ & $19.16 \pm 0.003^{\mathrm{b}}$ & $\leq 0.001$ \\
\hline Leucine & $52.35 \pm 0.017^{\mathrm{a}}$ & $45.22 \pm 0.009^{b}$ & $\leq 0.001$ \\
\hline Lysine & $170.12 \pm 0.015^{\mathrm{b}}$ & $175.99 \pm 0.006^{\mathrm{a}}$ & $\leq 0.001$ \\
\hline Methionine & $14.22 \pm 0.015^{\mathrm{a}}$ & $9.78 \pm 0.003^{\mathrm{b}}$ & $\leq 0.001$ \\
\hline Phenylalanine & $47.42 \pm 0.012^{\mathrm{a}}$ & $43.59 \pm 0.006^{\mathrm{b}}$ & $\leq 0.001$ \\
\hline Threonine & $6.49 \pm 0.003^{\mathrm{b}}$ & $6.63 \pm 0.006^{\mathrm{a}}$ & $\leq 0.001$ \\
\hline Tryptophan & $4.08 \pm 0.020^{\mathrm{a}}$ & $3.67 \pm 0.006^{\mathrm{b}}$ & $\leq 0.001$ \\
\hline Valine & $16.23 \pm 0.015^{\mathrm{a}}$ & $15.54 \pm 0.009^{\mathrm{b}}$ & $\leq 0.001$ \\
\hline Proline & $15.86 \pm 0.009^{b}$ & $23.67 \pm 0.009^{\mathrm{a}}$ & $\leq 0.001$ \\
\hline Glutamine & $94.38 \pm 0.021^{\mathrm{b}}$ & $97.19 \pm 0.010^{\mathrm{a}}$ & $\leq 0.001$ \\
\hline \multicolumn{4}{|l|}{ Non-essential amino acid } \\
\hline Alanine & $16.08 \pm 0.017^{b}$ & $18.02 \pm 0.028^{\mathrm{a}}$ & $\leq 0.001$ \\
\hline Aspartic acid & $22.15 \pm 0.003^{b}$ & $23.20 \pm 0.012^{\mathrm{a}}$ & $\leq 0.001$ \\
\hline Cystine & $1.90 \pm 0.006^{\mathrm{b}}$ & $3.86 \pm 0.006^{\mathrm{a}}$ & $\leq 0.001$ \\
\hline Glycine & $15.84 \pm 0.009^{b}$ & $23.88 \pm 0.006^{\mathrm{a}}$ & $\leq 0.001$ \\
\hline Serine & $5.88 \pm 0.006^{\mathrm{b}}$ & $6.81 \pm 0.006^{\mathrm{a}}$ & $\leq 0.001$ \\
\hline Tyrosine & $41.25 \pm 0.003^{\mathrm{a}}$ & $33.60 \pm 0.006^{\mathrm{b}}$ & $\leq 0.001$ \\
\hline
\end{tabular}

${ }^{\mathrm{a}, \mathrm{b}}$ Means in the same row with different superscripts differed by t-test.

${ }^{*}$ Data are expressed as mean \pm standard error of mean.

Abbreviations: FM, fish meal; PPM, suckermouth armored catfish meal.

Table 3 Ingredients and chemical compositions of the experimental diets

\begin{tabular}{|c|c|c|c|c|c|}
\hline \multirow{2}{*}{ Ingredient (g/100 g) } & \multicolumn{5}{|c|}{ Treatment } \\
\hline & Control & T1 & $\mathrm{T2}$ & T3 & T4 \\
\hline Corn & 36.00 & 36.00 & 36.45 & 36.45 & 36.45 \\
\hline Rice bran & 31.45 & 31.45 & 31.00 & 31.00 & 31.00 \\
\hline Soybean meal & 16.00 & 16.00 & 16.00 & 16.00 & 16.00 \\
\hline $\mathrm{FM}$ & 10.00 & 7.50 & 5.00 & 2.50 & - \\
\hline PPM & - & 2.50 & 5.00 & 7.50 & 10.00 \\
\hline Vitamin-mineral premix ${ }^{*}$ & 0.50 & 0.50 & 0.50 & 0.50 & 0.50 \\
\hline Soy bean oil & 5.00 & 5.00 & 5.00 & 5.00 & 5.00 \\
\hline Dicalcium phosphate & 1.00 & 1.00 & 1.00 & 1.00 & 1.00 \\
\hline Salt 1 & 0.05 & 0.05 & 0.05 & 0.05 & 0.05 \\
\hline Total & 100.00 & 100.00 & 100.00 & 100.00 & 100.00 \\
\hline Protein $(\%)$ & 19.8 & 19.95 & 20.1 & 20.25 & 20.4 \\
\hline $\mathrm{ME}(\mathrm{Kcal} / \mathrm{kg})^{\dagger}$ & 3158.2 & 3157.28 & 3156.35 & 3155.43 & 3154.5 \\
\hline
\end{tabular}

${ }^{*}$ Supplied per $100 \mathrm{~g}$ : vitamin A $1240 \mathrm{IU}$, vitamin $\mathrm{D}_{3} 310 \mathrm{ICU}$, vitamin E 1.7 IU, vitamin K $0.5 \mathrm{mg}$, vitamin $\mathrm{B}_{2} 0.5 \mathrm{mg}$, vitamin $\mathrm{B}_{3} 4.0$ $\mathrm{mg}$, vitamin $\mathrm{B}_{5} 1.5 \mathrm{mg}$, vitamin $\mathrm{B}_{12} 0.005 \mathrm{mg}$, folic acid $0.1 \mathrm{mg}$, pyridoxine $0.15 \mathrm{mg}$, Fe $3.0 \mathrm{mg}, \mathrm{Mn} 3.0 \mathrm{mg}, \mathrm{Zn} 4.5 \mathrm{mg}$, and Cu 7.5 mg.

$\dagger$ Calculated from NRC (1994) composition tables.

Abbreviations: ME, Metabolizable energy; FM, fish meal; PPM, suckermouth armored catfish meal. 
Table 4 Impact of the replacement of FM by PPM on growth performance in Pradu Hang Dam chickens

\begin{tabular}{|c|c|c|c|c|c|c|c|c|c|}
\hline \multirow{2}{*}{ Parameters } & \multicolumn{5}{|c|}{ Treatments } & \multirow{2}{*}{ SEM } & \multicolumn{3}{|c|}{ P-value } \\
\hline & Control & T1 & T2 & T3 & T4 & & ANOVA & Linear & Quadratic \\
\hline Initial weight (g) & 46.07 & 46.53 & 46.47 & 45.97 & 46.03 & 0.250 & 0.910 & 0.638 & 0.525 \\
\hline \multicolumn{10}{|l|}{ Final weight (g) } \\
\hline Phase 1 (at 28-day age) & $238.12^{b}$ & $263.75^{\mathrm{a}}$ & $232.50^{\mathrm{b}}$ & $231.62^{\mathrm{b}}$ & $235.62^{\mathrm{b}}$ & 3.558 & 0.022 & 0.589 & 0.593 \\
\hline Phase 2 (at 84 -day age) & 1212.77 & 1248.5 & 1209.73 & 1212.33 & 1184.5 & 15.764 & 0.800 & 0.511 & 0.246 \\
\hline \multicolumn{10}{|c|}{ Phase 1 ( 1 to 28 days of age) } \\
\hline $\operatorname{ADFI}(g / d)$ & 50.77 & 51.57 & 51.47 & 51.77 & 50.93 & 0.432 & 0.942 & 0.848 & 0.759 \\
\hline $\operatorname{ADG}(\mathrm{g} / \mathrm{d})$ & $6.93^{\mathrm{b}}$ & $7.93^{\mathrm{a}}$ & $6.83^{\mathrm{b}}$ & $6.73^{\mathrm{b}}$ & $6.56^{\mathrm{b}}$ & 0.120 & 0.002 & 0.091 & 0.094 \\
\hline FCR & $8.33^{\mathrm{b}}$ & $7.03^{\mathrm{a}}$ & $8.27^{\mathrm{b}}$ & $8.30^{\mathrm{b}}$ & $8.60^{\mathrm{b}}$ & 0.157 & 0.013 & 0.458 & 0.45 \\
\hline \multicolumn{10}{|c|}{ Phase 2 (29 to 84 days of age) } \\
\hline $\operatorname{ADFI}(g / d)$ & 83.43 & 84.33 & 83.9 & 82.97 & 82.97 & 0.493 & 0.886 & 0.412 & 0.279 \\
\hline $\operatorname{ADG}(g / d)$ & 17.37 & 17.5 & 17.37 & 17.43 & 17.07 & 0.261 & 0.989 & 0.675 & 0.241 \\
\hline FCR & 5.40 & 5.30 & 5.23 & 5.40 & 5.53 & 0.860 & 0.847 & 0.376 & 0.386 \\
\hline \multicolumn{10}{|c|}{ Overall (1 to 84 days of age) } \\
\hline $\operatorname{ADFI}(\mathrm{g} / \mathrm{d})$ & 72.57 & 73.47 & 73.03 & 72.5 & 72.2 & 0.352 & 0.812 & 0.549 & 0.346 \\
\hline $\operatorname{ADG}(g / d)$ & 13.87 & 14.23 & 13.77 & 13.87 & 13.57 & 0.192 & 0.870 & 0.499 & 0.254 \\
\hline FCR & 6.43 & 5.90 & 6.33 & 6.43 & 6.57 & 0.089 & 0.157 & 0.529 & 0.523 \\
\hline
\end{tabular}

${ }^{\mathrm{a}, \mathrm{b}}$ Different superscripts in the same row indicate significant differences $(\mathrm{P} \leq 0.05)$.

Chickens in the control group were fed a $100 \%$ FM diet.

Chickens in the T1, T2, T3, and T4 groups were fed a basal diet with PPM replacing FM at 25\%, 50\%, 75\% and 100\%, respectively. Abbreviations: ADFI, average daily feed intake; ADG, average daily gain; FCR, feed conversion ratio; FCG, feed cost per kg weight gain; SEM, standard error of mean; SEM, standard error of the mean; ANOVA, analysis of variance.

Table 5 Impact of the replacement of FM by PPM on the histology of duodenum in Pradu Hang Dam chickens

\begin{tabular}{|c|c|c|c|c|c|c|c|}
\hline \multirow{2}{*}{ Parameters } & \multicolumn{5}{|c|}{ Treatments } & \multirow{2}{*}{ SEM } & \multirow{2}{*}{ P-value } \\
\hline & Control & T1 & T2 & T3 & T4 & & \\
\hline Villus height $(\mu \mathrm{m})$ & $2915.27^{\mathrm{d}}$ & $3985.97^{\mathrm{a}}$ & $2995.34^{\mathrm{d}}$ & $3301.78^{c}$ & $3528.54^{\mathrm{b}}$ & 92.971 & 0.005 \\
\hline Villus width $(\mu \mathrm{m})$ & $301.74^{\mathrm{a}}$ & $251.02^{\mathrm{b}}$ & $200.80^{c}$ & $248.15^{\mathrm{b}}$ & $235.12^{b}$ & 7.725 & $\leq 0.001$ \\
\hline Crypt depth $(\mu \mathrm{m})$ & 1036.02 & 1034.10 & 1017.34 & 1095.15 & 1091.25 & 15.430 & 0.391 \\
\hline Crypt width $(\mu \mathrm{m})$ & $963.07^{\mathrm{a}}$ & $939.85^{\mathrm{a}}$ & $947.52^{\mathrm{a}}$ & $933.34^{\mathrm{a}}$ & $875.89^{\mathrm{b}}$ & 9.421 & 0.019 \\
\hline Crypt area $\left(\mu \mathrm{m}^{2}\right)$ & $21329.17^{\mathrm{c}}$ & $30963.35^{\mathrm{a}}$ & $30771.68^{\mathrm{b}}$ & $30825.63^{\mathrm{b}}$ & $30875.13^{\mathrm{ab}}$ & 874.734 & $\leq 0.001$ \\
\hline Muscularis mucosae thickness $(\mu \mathrm{m})$ & $100.25^{\mathrm{a}}$ & $94.22^{\mathrm{ab}}$ & $91.19^{\mathrm{b}}$ & $93.15^{\mathrm{b}}$ & $94.96^{\mathrm{ab}}$ & 1.060 & 0.046 \\
\hline Villus height per crypt depth ratio & $2.85^{\mathrm{b}}$ & $3.99^{\mathrm{a}}$ & $2.98^{\mathrm{b}}$ & $3.01^{\mathrm{b}}$ & $3.25^{\mathrm{b}}$ & 0.106 & $\leq 0.001$ \\
\hline
\end{tabular}

a,b,c,d Different superscripts in the same row indicate significant differences $(\mathrm{P} \leq 0.05)$.

Chickens in control group were fed a 100\% FM diet.

Chickens in the T1, T2, T3, and T4 groups were fed a basal diet with PPM replacing FM at 25\%, 50\%, 75\%, and 100\%; respectively.

Abbreviation: SEM, standard error of mean.

Table 6 Impact of the replacement of FM by PPM on the histology of jejunum in Pradu Hang Dam chickens

\begin{tabular}{lccccccc}
\hline \multirow{2}{*}{ Parameters } & \multicolumn{3}{c}{ Treatments } & \multicolumn{2}{c}{$\begin{array}{c}\text { P- } \\
\text { value }\end{array}$} \\
\cline { 2 - 6 } & Control & T1 & T2 & T3 & T4 & SE \\
\hline Villus height $(\mu \mathrm{m})$ & $2175.52^{\mathrm{d}}$ & $2974.93^{\mathrm{a}}$ & $2484.35^{\mathrm{b}}$ & $2263.74^{\mathrm{cd}}$ & $2374.54^{\mathrm{bc}}$ & 66.033 & 0.044 \\
Villus width $(\mu \mathrm{m})$ & $196.49^{\mathrm{a}}$ & $157.11^{\mathrm{d}}$ & $193.61^{\mathrm{ab}}$ & $186.01^{\mathrm{b}}$ & $169.17^{\mathrm{c}}$ & 3.647 & 0.050 \\
Crypt depth $(\mu \mathrm{m})$ & 916.27 & 940.95 & 970.72 & 997.46 & $1,026.86$ & 17.416 & 0.290 \\
Crypt width $(\mu \mathrm{m})$ & 957.75 & 946.29 & 979.02 & 950.24 & 954.06 & 9.916 & 0.885 \\
Crypt area $\left(\mu \mathrm{m}^{2}\right)$ & $39517.35^{\mathrm{a}}$ & $30698.13^{\mathrm{d}}$ & $30274.18^{\mathrm{c}}$ & $30814.18^{\mathrm{c}}$ & $31456.80^{\mathrm{b}}$ & 803.816 & $\leq 0.001$ \\
Muscularis mucosae thickness $(\mu \mathrm{m})$ & 101.61 & 95.66 & 97.03 & 102.48 & 95.65 & 1.134 & 0.484 \\
Villus height per crypt depth ratio & $2.40^{\mathrm{c}}$ & $3.20^{\mathrm{a}}$ & $2.59^{\mathrm{b}}$ & $2.29^{\mathrm{c}}$ & $2.33^{\mathrm{c}}$ & 0.088 & $\leq 0.001$ \\
\hline
\end{tabular}

a,b,c,d Different superscripts in the same row indicate significant differences $(\mathrm{P} \leq 0.05)$.

Chickens in the control group were fed a $100 \%$ FM diet.

Chickens in the T1, T2, T3 and T4 groups were fed a basal diet with PPM replacing FM at 25\%, 50\%, 75\%, and 100\%; respectively.

Abbreviation: SEM, standard error of mean. 
Table 7 Impact of the replacement of FM by PPM on the histology of ileum in Pradu Hang Dam chickens

\begin{tabular}{|c|c|c|c|c|c|c|c|}
\hline \multirow{2}{*}{ Parameters } & \multicolumn{5}{|c|}{ Treatments } & \multirow{2}{*}{ SEM } & \multirow{2}{*}{$\begin{array}{c}\text { P- } \\
\text { value }\end{array}$} \\
\hline & Control & T1 & T2 & T3 & T4 & & \\
\hline Villus height $(\mu \mathrm{m})$ & $1594.06^{\mathrm{d}}$ & $2422.24^{\mathrm{a}}$ & $1901.54^{\mathrm{c}}$ & $2057.84^{b}$ & $2125.72^{b}$ & 64.308 & $\leq 0.001$ \\
\hline Villus width $(\mu \mathrm{m})$ & $166.63^{c}$ & $167.93^{\mathrm{bc}}$ & $176.62^{\mathrm{ab}}$ & $168.89^{\mathrm{bc}}$ & $185.14^{\mathrm{a}}$ & 1.991 & 0.002 \\
\hline Crypt depth $(\mu \mathrm{m})$ & $742.94^{\mathrm{d}}$ & $797.55^{\mathrm{c}}$ & $700.42^{\mathrm{e}}$ & $920.64^{\mathrm{a}}$ & $873.35^{\mathrm{b}}$ & 19.394 & $\leq 0.001$ \\
\hline Crypt width $(\mu \mathrm{m})$ & $941.60^{\mathrm{a}}$ & $921.66^{\mathrm{ab}}$ & $874.2^{\mathrm{bc}}$ & $844.2^{\mathrm{b}}$ & $918.18^{\mathrm{ab}}$ & 10.553 & 0.006 \\
\hline Crypt area $\left(\mu \mathrm{m}^{2}\right)$ & $21029.98^{\mathrm{d}}$ & $20511.68^{\mathrm{e}}$ & $31363.13^{\mathrm{a}}$ & $28117.50^{\mathrm{c}}$ & $30807.50^{\mathrm{b}}$ & 1078.637 & $\leq 0.001$ \\
\hline Muscularis mucosae thickness $(\mu \mathrm{m})$ & 97.95 & 101.42 & 100.30 & 96.19 & 102.94 & 1.089 & 0.127 \\
\hline Villus height per crypt depth ratio & $2.17^{\mathrm{d}}$ & $3.05^{\mathrm{a}}$ & $2.74^{\mathrm{b}}$ & $2.24^{\mathrm{d}}$ & $2.45^{\mathrm{c}}$ & 0.079 & $\leq 0.001$ \\
\hline
\end{tabular}

a,b,c,d,e Different superscripts in the same row indicate significant differences $(\mathrm{P} \leq 0.05)$.

Chickens in the control group were fed a $100 \%$ FM diet.

Chickens in the T1, T2, T3, and T4 groups were fed a basal diet with PPM replacing FM at 25\%, 50\%, $75 \%$, and $100 \%$; respectively. Abbreviation: SEM, standard error of mean.
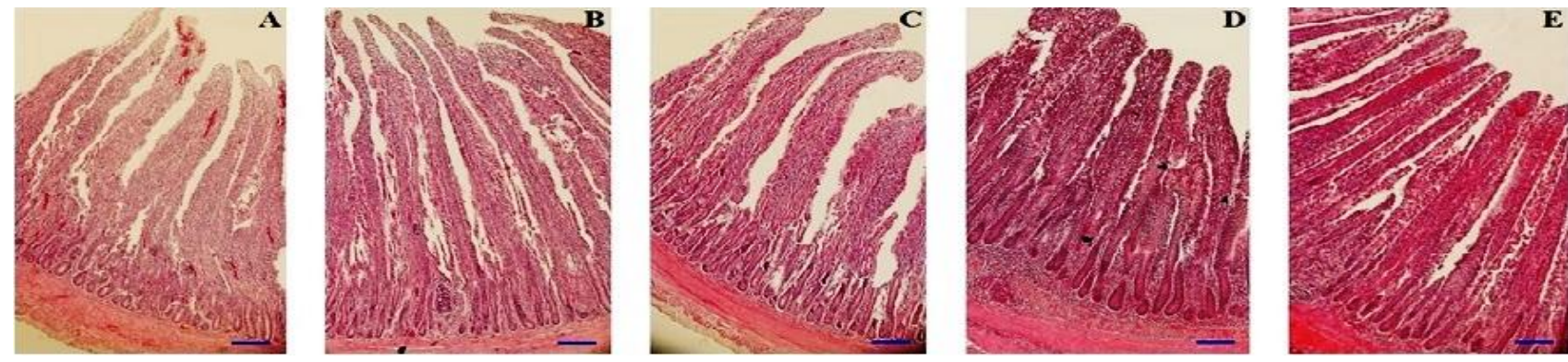

Fig. 1 Light photomicrographs of Haematoxylin and Eosin stained duodenal sections from Pradu Hang Dam chickens that received the basal diet with 100\% FM (control; A), and the basal diet with PPM 25\% (T1; B), 50\% (T2; C), 75\% (T3; D), and 100\% (T4; E). Magnification was $10 \times$ objective lens and scale bars represent $100 \mu \mathrm{m}$.
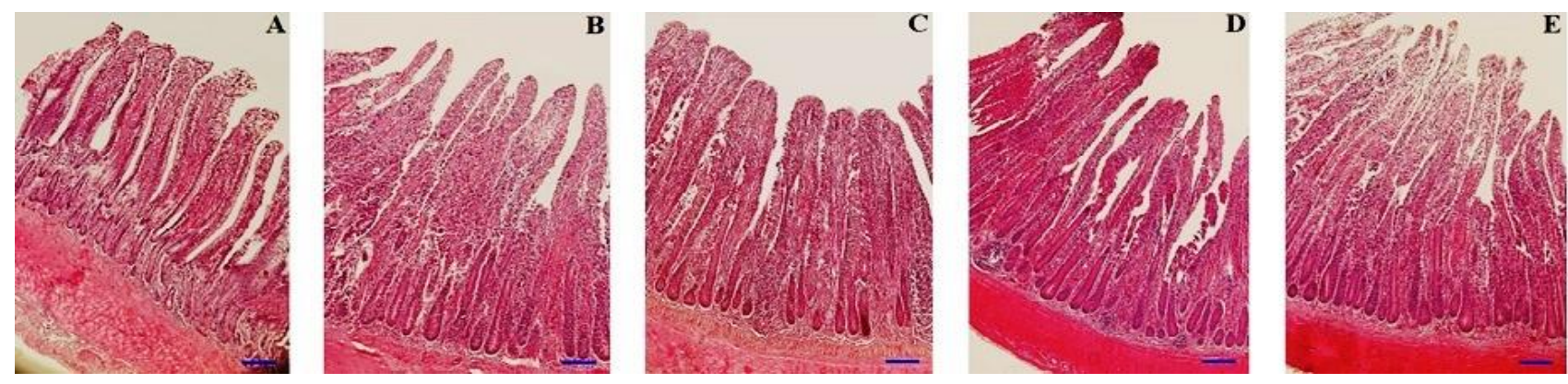

Fig. 2 Light photomicrographs of Haematoxylin and Eosin stained jejunal tissues from Pradu Hang Dam chickens that received the basal diet with 100\% FM (control; A), and the basal diet with PPM 25\% (T1; B), 50\% (T2; C), 75\% (T3; D), and 100\% (T4; E). Magnification was $10 \times$ objective lens and scale bars represent $100 \mu \mathrm{m}$.
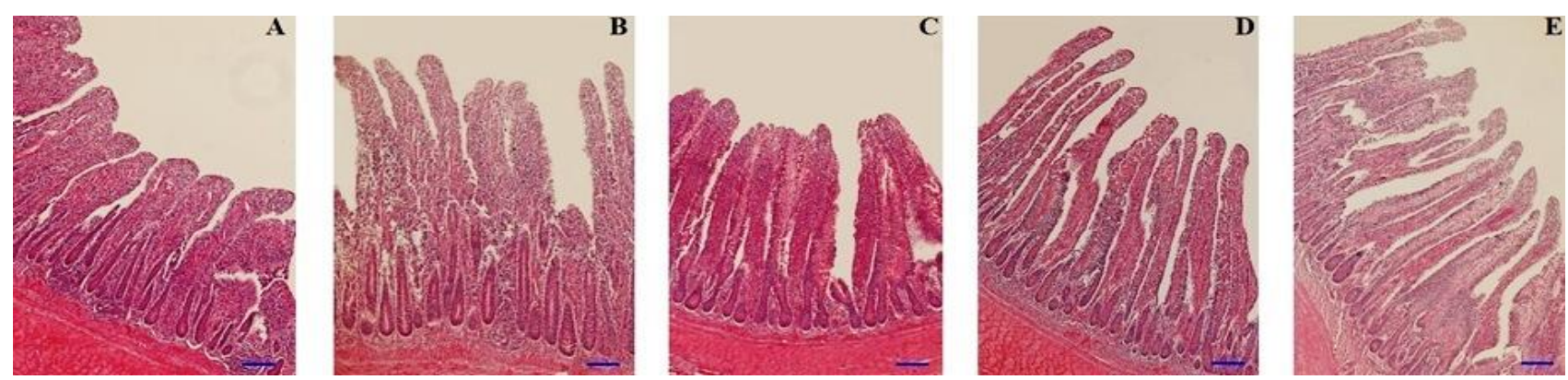

Fig. 3 Light photomicrographs of Haematoxylin and Eosin stained ileal tissues from Pradu Hang Dam chickens that received the basal diet with 100\% FM (control; A), and the basal diet with PPM 25\% (T1; B), 50\% (T2; C), 75\% (T3; D), and 100\% (T4; E). Magnification was $10 \times$ objective lens and scale bars represent $100 \mu \mathrm{m}$. 


\section{DISCUSSION}

To the researchers' knowledge, this is the first investigation intending to provide data on the growth performances and small intestinal histology responses to dietary treatments with replacement of FM by PPM in Thai native chickens (Pradu Hang Dam chickens). Research in improved growth performance and intestinal lumen health through the replacement of FM with PPM is essential for increasing utilization of alternative protein (fish) sources for chicken feed. Overall, growth performances did not differ among Pradu Hang Dum chickens receiving the PPM chicken diets, which implies that Pterygoplichthys pardalis contain a high level of protein to support chicken growth. In the present study, crude protein of PPM from suckermouth armored catfish (Pterygoplichthys pardalis) was $62.2 \%$, higher than the suckermouth catfish (Hypostomus plecostomus) at 37.1\%, which had been heavily distributed in Indonesia (Asnawi et al., 2015). In this study, the crude protein of PPM determination is consistent with the findings of Panase et al. (2018), which was $54.8 \%$ of crude protein. Although the utilization of Pterygoplichthys pardalis as a source of protein for chicken feed has not yet been evaluated, Panase et al. (2018); studied the replacement of commercial FM with 100\% PPM, without effectively altering growth performance, feed utilization, or blood biochemical indices in the diets of juvenile Mekong giant catfish (Pangasianodon gigas).

Interestingly, 25\% replacement of commercial FM with PPM in the diet of Thai native chickens improved intestinal histology as indicated by villus height and villus height per crypt depth ratio. According to the histological data of the small intestine, we suggest that the increased villus height obtained in the duodenal segment of the Thai native chickens receiving 25\% replacement of commercial FM with PPM in their diets could be due to improved duodenal lumen health. Measuring the height of the duodenal villi is another well-known indication of the duodenal lumen health of poultry (Jeurissen et al., 2002; Khambualai et al., 2009a; Chen et al., 2015; Tapingkae et al., 2016; Drażbo et al., 2018). The probable explanation for the increase in villus height includes the high level of glutamine in PPM. Investigations of seven-day-old chicks reported that the supplementation of $1 \%$ glutamine in the feed enhanced the development of villus height in the duodenum, jejunum, and ileum (Maiorka et al., 2016). In animal health, the gastrointestinal gut is the main digestive organ of glutamine utilization (Souba et al., 1990; Kao et al., 2013). This is possible due to the importance of glutamine as a substrate or energy source for the maturation of rapidly proliferating enterocytes (intestinal absorptive cells), which causes increased villus height (Abdulkarimi et al., 2019). As a result, boilers have become a popular model for the study of the mechanisms by glutamine as the main source of energy for cell division of enterocytes, providing energy for ATPdependent processes from Krebs cycle; including faster intracellular protein turnover and nutrient transport, and the consequent increase in villus height (Olubodun et al., 2015). Presumably, there is an important possible explanation for the enhanced villus height in each segment of the small intestines, as observed in this study.

Conclusion: According to the results of the current study, PPM can be utilized to replace FM in the diets of Thai native chickens, without any negative impacts on growth performance. Moreover, our results demonstrate that replacement of FM with PPM can be improved intestinal lumen health.

Acknowledgements: The authors would like to thank the Division of Animal Science, School of Agriculture and Natural Resources, University of Phayao for their assistance in the animal trial; and the Department of Animal and Aquatic Sciences, Faculty of Agriculture, Chiang Mai University, Thailand for their assistance in laboratory work and sample determination; and graduate school, Chiang Mai University, Thailand for the graduate scholarship. This research work was partially supported by Chiang Mai University.

\section{REFERENCES}

Abdulkarimi, R., M.H. Shahir, and M. Daneshyar (2019). Effects of dietary glutamine and arginine supplementation on performance, intestinal morphology and ascites mortality in broiler chickens reared under cold environment. AsianAustralas. J. Anim. Sci. 32(1): 110-117.

AOAC (2012). Official Methods of Analysis. 19th Ed. Association of Analytical Chemists, AOAC International, Washington (USA).

Asnawi, A., O. Sjofian, E. Sudjarwo, and S. Suyadi (2015). Potency of Sapu-Sapu fish (Hypostomus plecostomus) as feed supplement for local ducks. Int. J. Poult. Sci. 14(4): 240-244.

Chang, H.S. (2007). Overview of the world broiler industry: implications for the Philippines. Asian J Agric Dev. 4(2): 67-82.

Chen, Z., J. Xie, M.Y. Hu, J. Tang, Z.F. Shao, and H.M. Li (2015). Protective effects of $\gamma$-aminobutyric acid (GABA) on the small intestinal mucosa in heat-stressed Wenchang chicken. J. Ani. Plant Sci. 25(1): 78-87.

Cho, J. and I. Kim (2011). Fish meal-nutritive value. J. Anim. Physiol. Anim. Nutr. 95(6): 685-692.

Donkoh, A., D.M. Anang, C.C. Atuahene, B. Koomson, and H.G. Oppong (2001). Further studies on the use of solar-dried blood meal as a feed 
ingredient for poultry. J. Anim. Feed Sci. 10(1): 159-167.

Drażbo, A., D. Mikulski, J. Jankowski, and Z. Zduńczyk (2018). The effect of diets containing raw and fermented faba beans on gut functioning and growth performance in young turkeys. J. Anim. Feed Sci. 27(1): 65-73.

El-Sayed, M.Y., A.S. Al-Quffail, N.A. Al-Asgah, A.A. Abdel-Warith, and Y.S. Al-Hafedh (2018). Effect of dietary fish meal replacement by red algae, Gracilaria arcuate, on growth performance and body composition of Nile tilapia Oreochromis niloticus. Saudi J. Biol. Sci. 25(2): 198-203.

Indarsih, B., A. Asnawi, and D.K. Purnamasari (2016). Sapu-sapu fish (Hyposarcus pardalis) as a single protein source for laying mojosari ducks. J. Indones. Trop. Anim. Agric. 41(3): 117-124.

Jaturasitha, S., N. Chaiwang, and M. Kreuzer (2016). Thai native chicken meat: an option to meet the demands for specific meat quality by certain groups of consumers; a review. Anim. Prod. Sci. 57(8): 1582-1587.

Jeurissen, S.H.M., F. Lewis, J.D. van der Klis, Z. Mroz, J.M.J. Rebel, and A.A.H.M. ter Huurne (2002). Parameters and techniques to determine intestinal health of poultry as constituted by immunity, integrity, and functionality. Curr. Issues Intest. Microbiol. 3(1): 1-14.

Józefiak, A., B. Kierończyk, M. Rawski, J. Mazurkiewicz, A. Benzertiha, P. Gobbi, S. Nogales-Merida, S. Świątkiewicz, and D. Józefiak (2018). Full-fat insect meals as feed additive - the effect on broiler chicken growth performance and gastrointestinal tract microbiota. J. Anim. Feed Sci. 27(2): 131-139.

Kao, C., J. Hsu, V. Bandi, and F. Jahoor (2013). Alterations in glutamine metabolism and its conversion to citrulline in sepsis. Am. J. Physiol. Endocrinol. Metab. 304(12): E1359-E1364.

Khambualai, O., K. Yamauchi, K. Koge, and J. Kashimura (2009a). Morphology of the intestinal mucosa and growth performance of chickens fed diets containing sugar cane extract. J. Anim. Feed Sci. 18(2): 322-334.

Khambualai, O., K. Yamauchi, S. Tangtaweewipat, B. Cheva-Isarakul (2009b). Growth performance and intestinal histology in broiler chickens fed with dietary chitosan. Br. Poult. Sci. 50(5): 592597.

Maiorka, A., A.V.F. Silva, E. Santin, F. Dahlke, L.D.G. Bruno, I.C. Boleli, M. Macari, and H. Trautenmuller (2016). Effect of broiler breeder age and glutamine supplementation on the development of the intestinal mucosa of 7-dayold chicks. Braz. J. Poultry Sci. 18(1): 17-22.

Moharrery, A. and M. Mirzaei (2014). Growth characteristics of commercial broiler and native chickens as predicted by different growth functions. J. Anim. Feed Sci. 23(1): 82-89.

NRC (1994). Nutrient requirements of poultry. 9th Ed. The National Academies Press; Washington (USA). $176 \mathrm{p}$.

Olubodun, J.O., I. Zulkifli, A.S. Farjam, M. HairBejo, and A. Kasim (2015). Glutamine and glutamic acid supplementation enhances performance of broiler chickens under the hot and humid tropical condition. Ital. J. Ani. Sci. 14(1): 25-29.

Orfinger, A.B. and D.D. Goodding (2018). The global invasion of the suckermouth armored catfish genus Pterygoplichthys (Siluriformes: Loricariidae): Annotated list of species, distributional summary, and assessment of impacts. Zool. Stud. 57(1): 7-16.

Panase, P., S. Uppapong, S. Tuncharoen, J. Tanitson, K. Soontornprasit, and P. Intawicha (2018). Partial replacement of commercial fish meal with Amazon sailfin catfish Pterygoplichthys pardalis meal in diets for juvenile Mekong giant catfish Pangasianodon gigas. Aquacult. Rep. 12(1): 25-29.

Rakowska, M., B. Rek-Cieply, A. Sot, E. Lipinska, T. Kubinski, I. Barcz, and B. Afanasjew (1993). The effect of rye, probiotics and nisine on faecal flora and histology of the small intestine of chicks. J. Anim. Feed Sci. 2(1-2): 73-81.

Shafiq, M., A. Mahmud, J. Hussain, A. Basheer, S. Mehmood, M.T. Khan, S. Ahmad, and M. Asif (2018). Comparative production performance of four different Naked Neck chicken phenotypes on Pakistan. J. Anim. plant Sci. 28(1): 33-37.

Sokołowicz, Z., J. Krawczyk, and S. Świątkiewicz (2016). Quality of poultry meat from native chicken breeds-A review. Ann. Anim. Sci. 16(2): 347-368.

Souba, W.W., K. Herskowitz, R.M. Salloum, M.K. Chen, and T.R. Austgen (1990). Gut glutamine metabolism. J. Parenter. Enteral. Nutr. 14(4): 45S-50S.

Tapingkae, W., P. Yindee, and T. Moonmanee. 2016. Effect of dietary red yeast (Sporidiobolus pararoseus) supplementation on small intestinal histomorphometry of laying hens. J. Ani. Plant Sci. 26(4): 909-915.

White, J.A., R. Hart, and J.C. Fry (1986). An evaluation of the Waters Pico-Tag system for the aminoacid analysis of food materials. J. Lab. Autom. 8(4): 170-177. 